\title{
Research on the Teaching Management Mode of Applied Undergraduate Talents in the New Situation
}

Ying He

Guangxi University for Nationalities, Nanning 530006, Guangxi, China.

Project: Under the new situation, undergraduate colleges and higher vocational colleges jointly cultivate application-oriented undergraduate talents teaching management mode (No. 2018XJGY27).

Abstract: Under the current market economy system, the market's demand for application-oriented talents continues to increase, and the requirements for the comprehensive literacy and capabilities of talents are more stringent. In the new era, applied undergraduate colleges and universities must adapt to the changes in talent needs, and must do a good job of innovation in talent teaching management, optimizing the construction of curriculum teaching management mode, and promoting the realization of efficient talent training goals based on talent training goals and needs. In this regard, this article introduces the basic requirements of applied undergraduate talents under the new situation, analyzes the current basic status of talent teaching management in applied undergraduate colleges, and explores effective countermeasures for applied undergraduate talent teaching management under the new situation.

Keywords: New Situation; Applied Type; Undergraduate Talents; Teaching Management; Model

Application-oriented undergraduate colleges are an important part of higher education, and they mainly cultivate applied talents for the society. The current social division of labor is more detailed. In talent training, the practicality of knowledge and technical boundaries must be considered. Therefore, applied undergraduate colleges and universities need to develop corresponding standards and effective management models for talent training in order to achieve application-oriented the purpose of teaching and educating people in undergraduate institutions. The National Education Conference held in 2018 pointed out the orientation, future development direction and fundamental tasks of education. On this basis, applied undergraduate colleges put forward new requirements for talent training ${ }^{[1]}$.

\section{Talent training goals of applied undergraduate colleges in the new era}

\subsection{Occupational adaptability}

In the process of talent training in applied undergraduate colleges in the new era, the requirements for the ability, knowledge, and comprehensive literacy, etc., as well as the teaching methods and models of the students of the major need to be combined with the needs of professional practice to a certain extent. In the learning stage of students, let them strengthen their mental preparation in practice, cater to the new requirements of professional development in the new era for talents, and strengthen the cultivation of talents' knowledge, professional skills, qualities and abilities. Based on the different professional abilities of students and the market's requirements for the knowledge structure and quality system of talents with one specialization and multiple capabilities, it is necessary for talents in the new era to have certain professional and comprehensive skills, and have certain transfer capabilities, so that they can meet the future Need for changes in career positions.

Copyright(C) 2020 Ying He

doi: 10.18686/ahe.v4i10.2890

This is an open-access article distributed under the terms of the Creative Commons Attribution Non-Commercial License (http://creativecommons. org/licenses/by-nc/4.0/), which permits unrestricted non-commercial use, distribution, and reproduction in any medium, provided the original work is properly cited. 


\subsection{A knowledge structure with basic knowledge and expertise}

In the cultivation of applied undergraduate talents, in addition to the general knowledge teaching of talents, it is also necessary to strengthen the cultivation of students' professional expertise. In the context of quality education, quality education should be strengthened, and professional education and quality education should be combined. In the specific professional setting of students, focus on the cultivation of professional quality of talents with one specialization and multiple abilities, promote teachers to strengthen professional teaching design in teaching, ensure that the main modules and sub-modules are included in the curriculum teaching, break through the barriers of traditional courses, and pass professional foundation and specialization. It is composed of chemical courses, and cultivates application-oriented talents with strong professional foundation and special skills ${ }^{[2]}$.

\subsection{Correct employment orientation and cultivate correct professionalism}

In the training of applied undergraduate talents in the new era, teachers should combine the professional development and employment needs of future students, conduct scientific curriculum design, and focus on talent training. In the process of enrollment education, ideological and moral course teaching, employment guidance, etc., strengthen the training of advanced teaching concepts for the education subject, so that students can understand the society in advance, penetrate into the society, and make full ideological preparation and job preparation during the school. In teaching, the school can increase professional practical learning opportunities for students, so that students can feel the talents needed for future positions in specific practice, and clarify the direction of their future efforts. Considering that a large part of applied undergraduate talents come from non-key or local colleges and universities, it is necessary to accurately grasp the positioning, do a good job in the effective guidance of career development expectations, correct the work direction and attitude of future applied talents, and exercise their professionalism and cultivating a pragmatic work style are necessary to enhance the job competitiveness of future applied talents.

\section{Measures to construct a teaching management model for applied undergraduate talents under the new situation}

\subsection{Construct a diversified curriculum system}

In the new era, the market's demand for professional talents has changed, and the comprehensive requirements for talents have become more and more stringent. Therefore, applied undergraduate colleges and universities should change the traditional knowledge transfer method in the construction of the curriculum system for professional talent teaching and management. The main teaching model focuses on students' active exploration and practical ability in the learning process, so that students can be liberated from the indoctrination teaching model and become true independent explorers and discoverers of knowledge. In this regard, the practices of some developed countries are worth learning. For example, the "Xia Family Student Research Program" of California Institute of Technology proposes to allow all undergraduates to participate in research activities and formulate student research plans. Stanford students also encourage students to complete research projects independently, and provide students with a lot of direct participation in research institutions. Opportunity, in the training of undergraduate talents, more applications such as open teaching and discussion-based learning, a large number of research courses, and dedicated tutors, provide students with one-stop teaching services, and stimulate students' desire for exploration, to improve the conditions for practical exploration and cultivate students' exploration spirit ${ }^{[3]}$.

In the teaching and management of applied undergraduate talents, it is necessary to take advanced curriculum construction and development experience as examples, and actively construct a professional diversified curriculum system. On the one hand, it strengthens the cultivation of students' professional quality, and on the other hand, improves the comprehensive ability of students this kind of curriculum is very important for the training of talents with multiple skills.

\subsection{Improve the cross-professional curriculum system that combines generalist education and professional education}

At present, many colleges and universities still have certain shortcomings in the setting of professional courses, and disciplinary barriers are relatively obvious. In the curriculum setting, one-sided attention is paid to the professional courses 
of students, but the emphasis on general education is relatively insufficient, and the talents trained in this way have certain defects $^{[4]}$. For example, the basic knowledge and literacy of science and engineering students are relatively low. It is difficult for them to combine the natural sciences with the humanities, and they cannot meet the needs of interdisciplinary learning and application of knowledge and skills. In the liberal arts, the physiological thinking and ability are relatively poor, excessive perceptualization, and insufficient grasp of professional knowledge and skills. The talents cultivated in this way have greater limitations, which is not conducive to the improvement of future talent employment competitiveness. In addition, in the past, applied undergraduate colleges mostly focused on academic performance in the assessment and evaluation of talents. After the completion of the course, the student assessment is performed. The score becomes a key label to measure the performance of students, which makes it difficult for many students to feel in their studies to happiness. In this regard, we can learn from the MIT education model, take general education as the basic principle, actively construct a curriculum system that combines professional education and general education, build a cross-curricular system to a certain extent, focus on the cultivation of students' comprehensive quality, and break through the traditional curriculum. The unreasonable problem of the diversified interdisciplinary curriculum system is used to combine the professional learning and humanities learning of students to cultivate versatile talents.

\subsection{Carry out school-enterprise cooperation and cultivate talents' adaptability}

In the teaching and management of applied undergraduate talents, we should focus on cultivating students' job competitiveness, create opportunities for students to contact society and real positions, strengthen training in the job, and improve their job adaptability. In this regard, the school can actively develop school-enterprise cooperation with related enterprises, and build a school-enterprise cooperation and collaborative education model. This is an important measure for application-oriented undergraduate colleges to achieve the purpose of "practical education". The cultivation of talents in colleges and universities should be guided by the needs of the enterprise, improve students' professional quality, and improve their professional quality and core competitiveness in employment. The school can take advantage of the company's advantages in resources and funds to jointly build a professional talent practice base, arrange for students to perform internships, gain training in the company, and can also invite corporate professional and technical personnel to provide education and guidance to students and promote students' theory combine with practice to effectively improve the efficiency of talent training ${ }^{[5]}$.

\section{Conclusion}

Under the new situation, the application-oriented undergraduate talent teaching management model must adapt to the development requirements of the times and adapt to the demand trends of the talent market. It is necessary to build a diversified curriculum system, focus on the training of multi-functional and versatile talents, and adjust and optimize curriculum teaching Structure to promote continuous improvement of curriculum teaching quality.

\section{References}

1. Lan H, Sun R, Li Y, et al. Promoting the "four regressions" with listed courses as a starting point for the practical exploration of building a first-class undergraduate education. Education Teaching Forum 2020; (06): 175-176.

2. Wu C, Xie Y, Ge C. Exploration of the practice teaching mode of special education undergraduates with "equal emphasis on knowledge and action, combining education with health"—_ Taking Sichuan Normal University Special Education as an example. Modern Special Education 2019; (22): 20-26.

3. Feng Y. Research on the talent cultivation model of innovation and entrepreneurship education in newly-built general undergraduate universities_— Taking Harbin Petroleum Institute as an example. Theoretical Research and Practice of Innovation and Entrepreneurship 2018; 1(21): 91-92.

4. Gao Y. "Research before application" art design professional teaching Mode—Dalian Art University art design professional high-quality applied undergraduate talent cultivation. Art Education Research 2017; (13): 129.

5. Li J, Sun W, Mao C, et al. The construction and effectiveness of the teaching quality assurance system for the clinical medicine specialty: Taking the medical college of Hubei University of arts and science as an example. Journal of Hubei University of Arts and Science 2016; 37(05): 71-74. 